\title{
Intracellular localization and molecular heterogeneity of the sulphonylurea receptor in insulin-secreting cells
}

\author{
S. E. Ozanne, P. C. Guest, J. C. Hutton, C. N. Hales \\ Department of Clinical Biochemistry, University of Cambridge, Addenbrooke's Hospital, Cambridge, UK
}

\begin{abstract}
Summary Sulphonylureas stimulate insulin secretion by binding to a receptor in the pancreatic beta-cell plasma membrane resulting in inhibition of ATP-sensitive $\mathrm{K}^{+}$channels, membrane depolarization and thus influx of $\mathrm{Ca}^{2+}$ through voltage-dependent $\mathrm{Ca}^{2+}$ channels. Sulphonylureas can also induce hormone release at fixed membrane potentials without $\mathrm{Ca}^{2+}$ entry suggesting that these drugs may have other modes of action. We have determined whether different forms of sulphonylurea-binding proteins are present in insulin-secreting cells and their subcellular localization by density gradient centrifugation. Binding studies using $\left[{ }^{3} \mathrm{H}\right]$-glibenclamide showed that islet and insulinoma membranes contained a single high affinity sulphonylurea binding site $\left(\mathrm{K}_{\mathrm{d}}=\right.$ $1 \mathrm{nmol} / \mathrm{l})$. Photo-crosslinking of the drug to the membranes resulted in labelling of two proteins with ap-
\end{abstract}

parent molecular weights of 170 and $140 \mathrm{kDa}$. The same analyses of insulinoma subcellular fractions showed that the majority ( $>90 \%$ ) of binding proteins were localized to intracellular membranes with only minor levels $(<10 \%)$ on plasma membranes. The $170 \mathrm{kDa}$ sulphonylurea binding protein was present in both plasma and granule membrane fractions whereas the $140 \mathrm{kDa}$ form was not present in the plasma membrane fraction. The differences in the molecular forms and subcellular distribution of the receptor are consistent with sulphonylureas having multiple sites of action in the pancreatic beta cell. [Diabetologia (1995) 38: 277-282]

Key words Non-insulin-dependent diabetes mellitus, insulin, sulphonylurea receptors, islets, glibenclamide, secretory granule.
Sulphonylureas have been used to treat non-insulindependent diabetic patients for over 30 years. These drugs stimulate insulin secretion by inhibiting ATPsensitive potassium $\left(\mathrm{K}_{\text {АTP }}\right)$ channels which leads to depolarization of the plasma membrane, activation of voltage-dependent $\mathrm{Ca}^{2+}$ channels and an increase in cytoplasmic $\mathrm{Ca}^{2+}$ levels [1]. High-affinity sulphonylurea binding sites have been reported in a number of insulin-secreting cells including HIT cells and murine islets [2-4]. Photoaffinity labelling studies us-

Received: 5 July 1994 and in revised form: 2 September 1994

Corresponding author: Dr. S. E. Ozanne, Department of Clinical Biochemistry, University of Cambridge, Addenbrooke's Hospital, Hills Road, Cambridge, CB2 2QR, UK

Abbreviations: NEDH rats, New England Deaconess Hospital rats; DMEM, Dulbecco's modified Eagle's medium; PMSF, phenylmethylsulphonyl fluoride; ER, endoplasmic reticulum. ing $\left[{ }^{3} \mathrm{H}\right]$-glibenclamide [5] and $\left[{ }^{125} \mathrm{I}\right]$-glibenclamide $[6,7]$ have shown that the binding protein has an apparent molecular weight of $140 \mathrm{kDa}$ in HIT cells, as determined by SDS-PAGE under reducing conditions. Recent radiation inactivation studies have shown that the native sulphonylurea receptor in MIN6 beta-cell membranes is a multimer with a molecular mass of $250 \mathrm{kDa}$ [8]. The mechanism by which sulphonylurea binding elicits $\mathrm{K}_{\mathrm{ATP}}$-channel inhibition has not been elucidated, although patch clamp studies have shown that the process is $\mathrm{Mg}^{2+} \mathrm{de}-$ pendent [9]. Studies combining patch clamp, drug binding and secretion analyses of the CRI-G1 and CRI-D11 cell lines, which differ in their sensitivity to sulphonylureas, have shown that the receptor and channel moieties are closely-associated in the plasma membrane although they appear to reside on separate polypeptide chains [10]. 
Apart from the inhibitory effect of sulphonylureas on plasma membrane $\mathrm{K}_{\mathrm{ATP}}$ channels, sulphonylureas may stimulate insulin secretion by other mechanisms. Studies using electrically-permeabilized RIN$\mathrm{m} 5 \mathrm{f}$ cells have shown that tolbutamide can stimulate insulin secretion by a mechanism which is not dependent on changes in membrane potential [11]. Similarly, Ammala et al. [12] have shown that tolbutamide enhanced the rate of exocytosis from depolarized mouse beta cells without any change in the existing $\mathrm{Ca}^{2+}$ current. Since ultrastructural studies show that $\left[{ }^{3} \mathrm{H}\right]$-glibenclamide associates with secretory granules in rat islets of Langerhans [13], it is proposed that the drug may interact with the secretory machinery. However, the nature of such intracellular sulphonylurea binding sites and their relationship to the receptor involved in $\mathrm{K}_{\mathrm{ATP}}$ channel regulation have not been characterized.

The aim of the present study was to investigate the molecular complexity of sulphonylurea binding proteins in insulin-secreting cells by glibenclamide binding studies and photoaffinity-labelling analyses. The subcellular distribution of different molecular forms was determined by density gradient centrifugation analyses of transplantable insulinoma tissue.

\section{Materials and methods}

Materials. Analytical grade biochemicals were obtained from Sigma Chemical Co. or BDH Chemicals (both of Poole, Dorset, UK), unless stated otherwise. $\left[{ }^{3} \mathrm{H}\right]$-glibenclamide $(50.7 \mathrm{Ci} /$ mmol) was obtained from NEN-Dupont (Stevenage, Herts., UK).

Tissues. Insulinomas were propagated in New England Deaconess Hospital (NEDH) rats as described previously [14]. Tumours were removed and tissue was scraped from the fibrous capsules into Hanks saline [(in mmol/1) $137 \mathrm{NaCl}, 5.4 \mathrm{KCl}$, $1.67 \mathrm{MgSO}_{4}, \quad 4 \mathrm{CaCl}_{2}, \quad 0.34 \mathrm{Na}_{2} \mathrm{HPO}_{4}$ and $4.2 \mathrm{NaHCO}_{3}$ (pH 7.4)]. All subsequent procedures were performed at $4^{\circ} \mathrm{C}$. Cells were isolated from insulinoma tissue by Percoll density gradient centrifugation as described previously [15] and used immediately. The CRI-G1 and CRI-D11 insulin-secreting cell lines, derived initially from transplantable rat insulinoma cells, were cultured in Dulbecco's Modified Eagle's Medium (DMEM) containing $10 \%$ fetal calf serum (both from Flow Laboratories, Irvine, Scotland, UK) and passaged at 4-7 day intervals as described by Carrington et al. [16]. Islets of Langerhans were isolated from the pancreata of 8-12-week-old NEDH rats by collagenase digestion followed by purification on Histopaque density gradients as described by Guest et al. [17]. Islets were cultured overnight in DMEM containing $11 \mathrm{mmol} / \mathrm{l}$ glucose and $10 \%$ fetal calf serum.

Subcellular fractionation of insulinomas. Insulinoma tissue was homogenized in isotonic media and fractionated by density gradient centrifugation on Nycodenz step gradients as described by Hutton et al. [18]. This yielded four membrane fractions designated as A, B, C and D in order of increasing density. Fractions were stored in the presence of $100 \mu \mathrm{mol} / 1$ phenylmethylsulphonyl fluoride (PMSF), $20 \mu \mathrm{mol} / 1$ trans-Epoxy-
succinyl-L-leucylamido(4-guanidino)-butane (E-64) and $10 \mu \mathrm{mol} / \mathrm{l}$ pepstatin $\mathrm{A}$ under liquid nitrogen prior to analysis.

Membrane preparation. Islets, CRI-G1 and CRI-D11 cells were lysed and crude membrane fractions prepared by ultracentrifugation as described previously [10]. Samples were resuspended in $50 \mathrm{mmol} / 1$ Tris/ $\mathrm{HCl}$ ( $\mathrm{pH} \mathrm{7.4)} \mathrm{containing}$ $100 \mathrm{mmol} / 1 \mathrm{PMSF}, 10 \mathrm{mmol} / 1$ Pepstatin A and $20 \mathrm{mmol} / \mathrm{l} \mathrm{E64}$ and stored under liquid nitrogen prior to use.

Salt washing of insulinoma membranes. Insulinoma membrane fractions were pelleted by centrifugation for $30 \mathrm{~min}$ at $100,000 \times g$ (Sorvall T-1270; Du Pont (U.K) Ltd., Stevenage, Merts, UK), then resuspended in $2 \mathrm{ml}$ of $10 \mathrm{mmol} / \mathrm{l}$ $\mathrm{NH}_{4} \mathrm{HCO}_{3}$ and sonicated for $10 \mathrm{~s}$ at $3 \mu \mathrm{m}$ (MSE Sonifier, Crawley, Sussex, UK). Centrifugation was repeated and the pellets were resuspended in $2 \mathrm{ml}$ of $10 \mathrm{mmol} / 1 \mathrm{NH}_{4} \mathrm{HCO}_{3}$ containing $1 \mathrm{~mol} / 1 \mathrm{NaCl}$ and $1 \mathrm{mmol} / 1$ EDTA, sonicated and centrifuged as above. The pellet was resuspended in $2 \mathrm{ml}$ of $10 \mathrm{mmol} / 1 \mathrm{NH}_{4} \mathrm{HCO}_{3}$ and the sonication and centrifugation steps were repeated. The membranes were stored under liquid nitrogen in $1 \mathrm{ml}$ of $50 \mathrm{mmol} / 1$ Tris $/ \mathrm{HCl} \mathrm{pH} 7.4$ containing the protease inhibitors described above. Control (non-salt washed) membranes were treated in an identical manner except all procedures were performed in $50 \mathrm{mmol} / 1$ Tris $/ \mathrm{HCl}(\mathrm{pH} 7.4)$.

$\left.{ }^{3} H\right]$-glibenclamide binding studies. Membranes prepared from islets, insulinoma, CRI-G1 and CRI-D11 cells (25 $\mu \mathrm{g}$ protein) were incubated for $2 \mathrm{~h}$ at room temperature in $0.5 \mathrm{ml}$ assay buffer $(50 \mathrm{mmol} / 1 \mathrm{Tris} / \mathrm{HCl} \mathrm{pH} \mathrm{7.4)} \mathrm{containing} \mathrm{the} \mathrm{indicat-}$ ed concentrations of $\left[{ }^{3} \mathrm{H}\right]$-glibenclamide $(50.9 \mathrm{Ci} / \mathrm{mmol}, \mathrm{Du}$ Pont [UK] Ltd). Incubations were terminated by addition of $2 \mathrm{ml}$ of ice-cold buffer and bound ligand was collected by rapid vacuum filtration onto $2.5-\mathrm{cm}$ diameter GF/B filter disks (Whatman International Ltd, Maidstone, Kent, UK). Filters were washed with $4 \times 2 \mathrm{ml}$ of ice-cold buffer and the bound radioactivity determined by liquid scintillation counting using OptiPhase HiSafe II (LKB Scintillation Products, Loughborough, Leicestershire, UK) and a Packard liquid-scintillation spectrometer (Canberra Packard, Slaugh, Berkshire, UK).

Assay protocols. Protein was determined by a dye binding method using bovine serum albumin as standard [19]. Insulin was measured by radioimmunoassay as described previously [20]. Spectrophotometric assays were performed for cytochrome oxidase [21], NADPH-cytochrome c reductase [22] and alkaline phosphatase [23]. $\beta-\mathrm{N}$-acetylglucosaminidase was determined by a fluorometric method [24].

Photoaffinity labelling. Membrane fractions from each cell type $(100 \mu \mathrm{g}$ protein) were incubated for $2 \mathrm{~h}$ at room temperature in $60 \mu \mathrm{l}$ of sodium phosphate buffer ( $\mathrm{pH} 7.5$ ) containing $10 \mathrm{nmol} / 1\left[{ }^{3} \mathrm{H}\right]$-glibenclamide. The samples were irradiated for $15 \mathrm{~min}$ at $312 \mathrm{~nm}$ in a Stratalinker (Stratagene, La Jolla, Calif., USA) and then combined with an equal volume of $2 \times$ concentrated sample loading buffer $(0.25 \mathrm{~mol} / \mathrm{l}$ Tris $/ \mathrm{HCl} \mathrm{pH} 9.2 \%$ SDS, $12 \%$ sucrose, $20 \mathrm{mmol} / \mathrm{l}$ EDTA, $130 \mathrm{mmol} / \mathrm{l}$ dithiothreitol). Samples were subjected to SDS-polyacrylamide gel electrophoresis on slab gels $(15 \times 15 \times 0.15 \mathrm{~cm})$ polymerized from $10 \%$ (weight/volume) acrylamide and $0.13 \% \mathrm{NN}^{\prime}$-methylenebisacrylamide using the discontinuous buffer system of Laemmli [25]. Gels were impregnated for fluorography with $20 \%$ (weight/volume) 2, 5-diphenyloxazole in acetic acid, vacuum dried and exposed to Kodak Scientific Imaging Film (Eastman Kodak Company, New York, N. Y., USA) at $70^{\circ} \mathrm{C}$. 


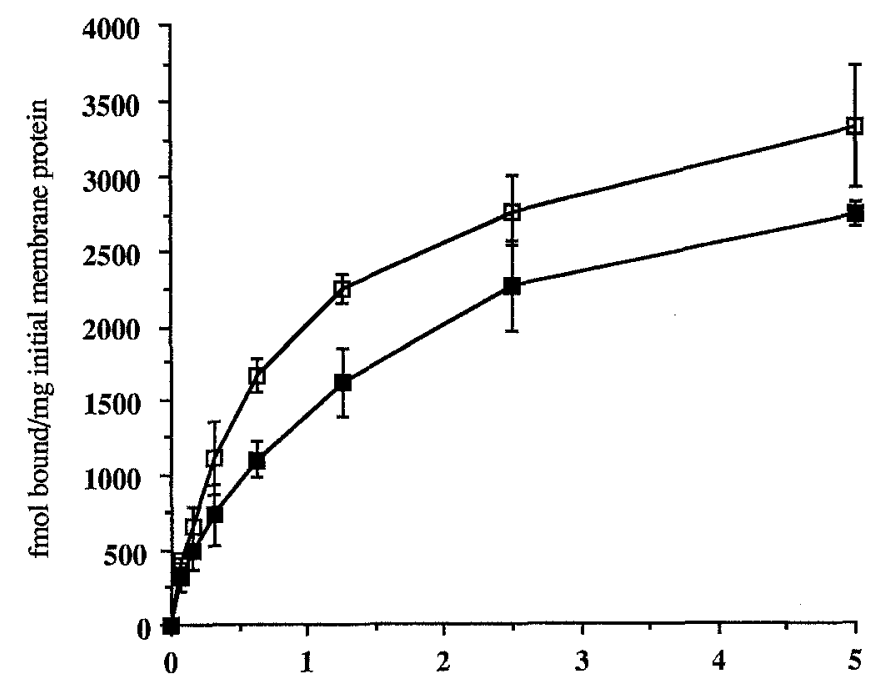

[ $\left.{ }^{3} \mathrm{H}\right]$-Glibenclamide (nmol//)

Fig. 1. Effect of $\mathrm{NaCl}$ and EDTA washes on $\left[{ }^{3} \mathrm{H}\right]$-glibenclamide binding to insulinoma membranes. Insulinoma membranes were washed with $10 \mathrm{mmol} / 1 \mathrm{NH}_{4} \mathrm{HCO}_{3}$ containing $1 \mathrm{~mol} / \mathrm{l}$ $\mathrm{NaCl}$ and $2 \mathrm{mmol} / 1$ EDTA and incubated with the indicated concentrations of $\left[{ }^{3} \mathrm{H}\right]$-glibenclamide as described in the methods section. Bound radioactivity was collected by vacuum filtration onto $\mathrm{GF} / \mathrm{B}$ disks and determined by liquid scintillation counting. Non-specific binding was determined in the presence of $1 \mu \mathrm{mol} / 1 \mathrm{glibenclamide}$ and was always less than $10 \%$ of the total bound counts. Results are expressed as fmol $\left[{ }^{3} \mathrm{H}\right]$-glibenclamide bound $/ \mathrm{mg}$ initial membrane protein after subtraction of non-specific binding and are the mean \pm SEM of three experiments, each performed in triplicate - - washed; $-\square$ - control

\section{Results}

Binding studies on total membranes. High affinity glibenclamide binding sites were detected in total membranes prepared from transplantable rat insuli- noma cells (Fig. 1). The affinity of the insulinoma receptors $(1.17 \pm 0.18 \mathrm{nmol} / \mathrm{l})$ was similar to those expressed in the CRI-G1 cell line $\left(\mathrm{K}_{\mathrm{d}}=1.31 \pm\right.$ $0.06 \mathrm{nmol} / \mathrm{l})$, although the $\mathrm{B}_{\max }$ was approximately three-fold higher $(4.3 \pm 0.2$ vs $1.4 \pm 0.1 \mathrm{pmol} / \mathrm{mg})$. Washing of the insulinoma membranes with $\mathrm{NaCl}-$ and EDTA-containing solutions had no effect on the affinity of the receptor for glibenclamide $\left(\mathrm{K}_{\mathrm{d}}\right.$ of $1.23 \pm 0.3 \mathrm{nmol} / \mathrm{l})$ and only slightly reduced the number of receptors detected $\left(\mathrm{B}_{\max }\right.$ of $3.8 \pm 0.1 \mathrm{pmol} / \mathrm{mg}$ initial protein). However, the specific activity of receptor binding increased from $4.3 \pm 0.2$ to $16.5 \pm$ $0.5 \mathrm{pmol} / \mathrm{mg}$ following membrane washing.

\section{Subcellular fractionation of insulinoma membranes.} Nycodenz density gradient centrifugation of insulinoma tissue produced four membrane fractions designated A, B, C and D, in order of increasing density. Analysis of selected marker proteins showed that fraction A was enriched in plasma membranes, fraction B was a mixture of plasma membranes and secretory granules, fraction $C$ was enriched in secretory granules and fraction $\mathrm{D}$ was a mixture of granules, mitochondria, lysosomes and endoplasmic reticulum (ER) (Table 1). Glibenclamide binding studies showed that the sulphonylurea receptor was distributed across the gradient with slightly higher specific activities detected in fractions $\mathrm{B}$ and $\mathrm{C}$ (Table 1). Thus, from total recoveries of each fraction it was estimated that fractions $\mathrm{A}, \mathrm{B}, \mathrm{C}$ and $\mathrm{D}$ contained $1 \%, 3 \%, 30 \%$ and $66 \%$ of the total recovered cellular binding sites, respectively. This was similar to the distribution of insulin secretory granules as fractions $\mathrm{A}, \mathrm{B}, \mathrm{C}$ and $\mathrm{D}$ contained $0.5 \%, 2 \%$, $35 \%$ and $62.5 \%$ of the total recovered immunoreactive insulin, respectively, whereas ER, mitochondria
Table 1. Distribution of sulphonylurea receptors and marker proteins in subcellular fractions. Subcellular fractions prepared from rat insulinoma tissue from 15 rats were assayed for glibenclamide binding and the following marker proteins:
(1) secretory granules (insulin), (2) lysosomes ( $\beta$ - $N$-acetylglucosaminidase), (3) mitochondria (cytochrome c oxidase), (4) Endoplasmic reticulum (NADPH-cytochrome c reductase) and (5) plasma membranes (alkaline phosphatase)

\begin{tabular}{|c|c|c|c|c|c|c|c|c|c|c|}
\hline \multirow[t]{2}{*}{ Marker } & \multirow{2}{*}{$\begin{array}{l}\text { Specific activity } \\
\text { units }\end{array}$} & \multicolumn{4}{|c|}{ Fraction } & \multirow{2}{*}{$\begin{array}{l}\text { Total activity } \\
\text { units }\end{array}$} & \multicolumn{4}{|c|}{ Fraction } \\
\hline & & $A$ & B & $\mathrm{C}$ & $\mathrm{D}$ & & $\bar{A}$ & B & $\mathrm{C}$ & $\mathrm{D}$ \\
\hline Insulin & (nmol/mg) & 5 & 12 & 21 & 15 & (nmol) & 2 & 9.6 & 168 & 300 \\
\hline $\begin{array}{l}\beta-N \text {-Acetylglu } \\
\text { cosaminidase }\end{array}$ & (arbitrary units) & 24 & 25 & 30 & 100 & $\begin{array}{l}\text { (arbitrary } \\
\text { units) }\end{array}$ & 9.6 & 20 & 240 & 2000 \\
\hline $\begin{array}{l}\text { Alkaline } \\
\text { phosphatase }\end{array}$ & $\mathrm{nmol} \cdot \min ^{-1} \cdot \mathrm{mg}$ & 930 & 467 & 127 & 52 & $(\mathrm{nmol} / \mathrm{min})$ & 372 & 373.6 & 1016 & 1040 \\
\hline $\begin{array}{l}\text { NADPH- } \\
\text { cytochrome c } \\
\text { reductase }\end{array}$ & $\mathrm{nmol} \cdot \min ^{-1} \cdot \mathrm{mg}$ & 4 & 7 & 38 & 102 & (nmol/min) & 1.6 & 5.6 & 304 & 2040 \\
\hline $\begin{array}{l}\text { Cytochrome c } \\
\text { oxidase }\end{array}$ & $\mathrm{nmol} \cdot \mathrm{min}^{-1} \cdot \mathrm{mg}$ & 26 & 27 & 28 & 94 & $(\mathrm{nmol} / \mathrm{min})$ & 10.4 & 21.6 & 224 & 1880 \\
\hline $\begin{array}{l}\text { Glibenclamide } \\
\text { binding }\end{array}$ & $(\mathrm{fmol} / \mathrm{mg})$ & 664 & 1025 & 925 & 825 & $(\mathrm{fmol})$ & 267 & 820 & 7400 & 16500 \\
\hline Protein & & - & - & - & - & $(\mathrm{mg})$ & 0.4 & 0.8 & 8 & 20 \\
\hline
\end{tabular}




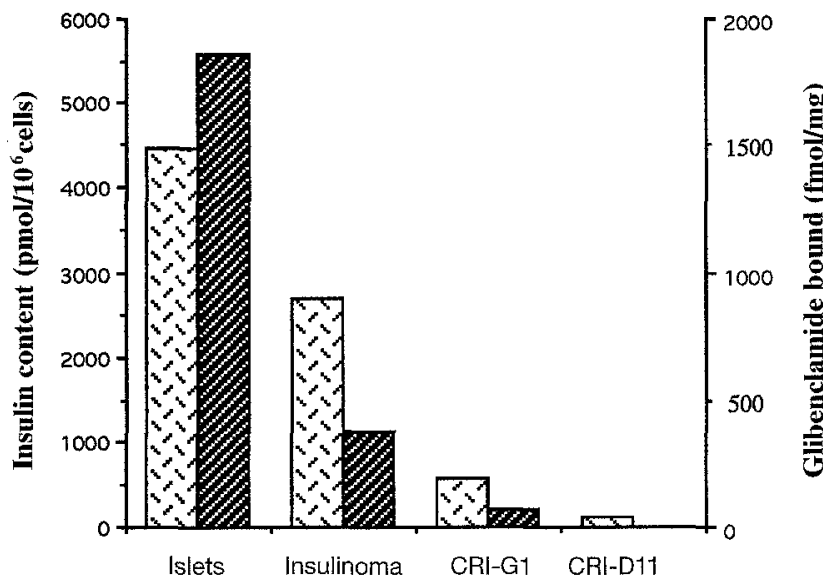

Fig. 2. Comparison of insulin content and sulphonylurea binding in insulin-secreting cells. The indicated membranes were incubated in $0.2 \mathrm{nmol} / 1\left[{ }^{3} \mathrm{H}\right]$-glibenclamide for $2 \mathrm{~h}$ and then bound radioactivity was collected by vacuum filtration onto GF/B disks and determined by liquid scintillation counting as described in the methods section. Non-specific binding (NSB) was determined in the presence of $1 \mu \mathrm{mol} / \mathrm{l}$ glibenclamide. Results are expressed as fmol bound/mg protein after subtraction of NSB and are the mean \pm SEM of three experiments. Insulin was determined by radioimmunoassay and results are the mean $\pm S E M$ of three experiments each performed in triplicate Sulphonylurea receptors; Insulin

and lysosomes showed a different distribution (Table 1 ).

Insulin and sulphonylurea receptor levels in different beta-cell sources. Insulin radioimmunoassay and glibenclamide binding studies showed that there was a strong correlation $(R=0.92)$ between cellular insulin content and number of sulphonylurea receptors present in the corresponding total cellular membranes with the highest levels of each found in pancreatic islets and the lowest found in CRI-D11 cells (Fig.2).

Photoaffinity labelling studies. Ultraviolet-crosslinking of $\left[{ }^{3} \mathrm{H}\right]$-glibenclamide to membranes prepared from pancreatic islets, insulinoma and CRI-G1 cells labelled two proteins of apparent molecular weights $140 \mathrm{kDa}$ and $170 \mathrm{kDa}$ (Fig.3). There was a difference in the relative levels of these two proteins in the different cell types. In CRI-G1 cells the $140 \mathrm{kDa}$ species was the predominant component, whereas the $170 \mathrm{kDa}$ form was more abundant in islets and insulinoma tissue. The two forms of the receptor were also distributed differently in different insulinoma subcellular membrane fractions (Fig.4). The plasma membrane- and secretory granule- enriched fractions $\mathrm{A}, \mathrm{B}$ and $\mathrm{C}$ contained only the $170 \mathrm{kDa}$ form of the receptor whereas fraction $\mathrm{D}$, which contained lysosomes, mitochondria and ER in addition to secretory granules, had both the $170 \mathrm{kDa}$ and $140 \mathrm{kDa}$ forms of the receptor. Neither of the

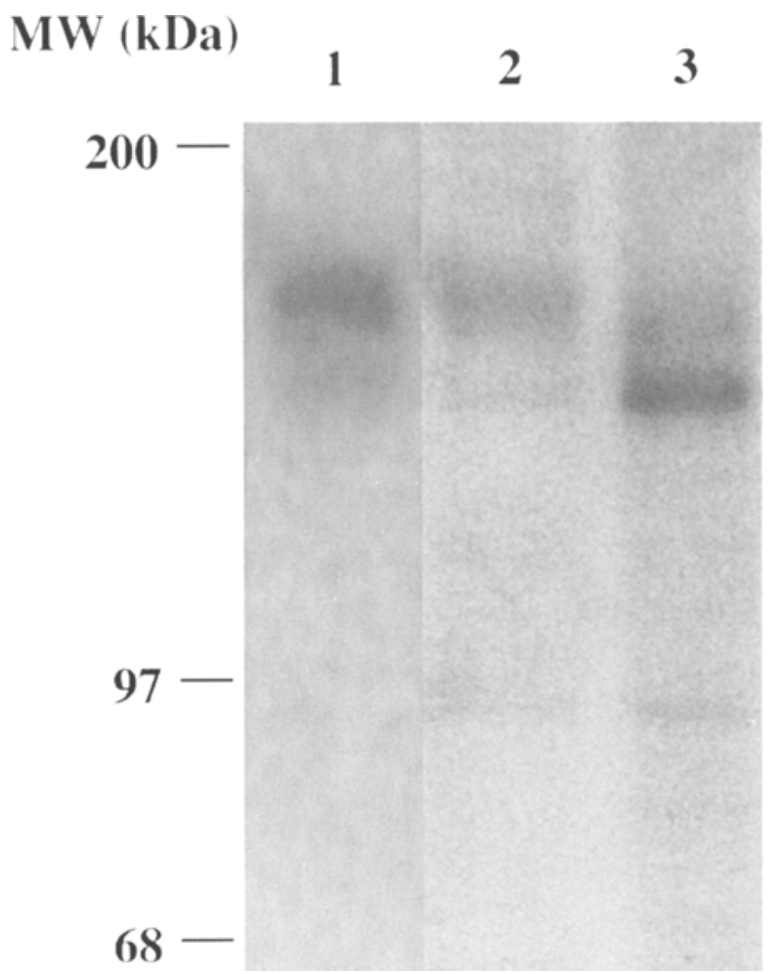

Fig. 3. Photoaffinity labelling of sulphonylurea receptors present in islets, insulinoma and CRI-G1 membranes. Membranes $(50 \mu \mathrm{g})$ were incubated with $10 \mathrm{nmol} / \mathrm{l}\left[{ }^{3} \mathrm{H}\right]$ glibenclamide and irradiated at $302 \mathrm{~nm}$ for $15 \mathrm{~min}$ as described in the methods section. Labelled proteins in islets (track 1), insulinoma (track 2) and CRI-G1 (track 3) membranes were detected by SDS-PAGE and fluorography

proteins were labelled in the presence of $1 \mu \mathrm{mol} / \mathrm{l}$ unlabelled glibenclamide (Fig. 4).

\section{Discussion}

Sulphonylurea receptors have been identified in a variety of tissues including pancreatic beta cells, ventricular myocytes and cerebral cortex [1]. The molecular structure of the receptor is poorly understood, although it has been suggested that it is glycated based on its ability to bind wheatgerm agglutinin and its apparent increase in mobility on SDS-PAGE gels following treatment with endoglycosidase $\mathrm{F}$ [26]. The present study showed that tumours propagated in NEDH rats express sulphonylurea receptors with a single type of high affinity binding site. These receptors remain associated with the membrane following stringent washing procedures suggesting that they might be either integral membrane proteins or covalently attached to the membrane. This observation is consistent with recent structural studies which proposed that the receptor contains multiple transmembrane spanning domains [27].

Sulphonylurea binding studies of insulinoma subcellular fractions showed that there was a high speci- 


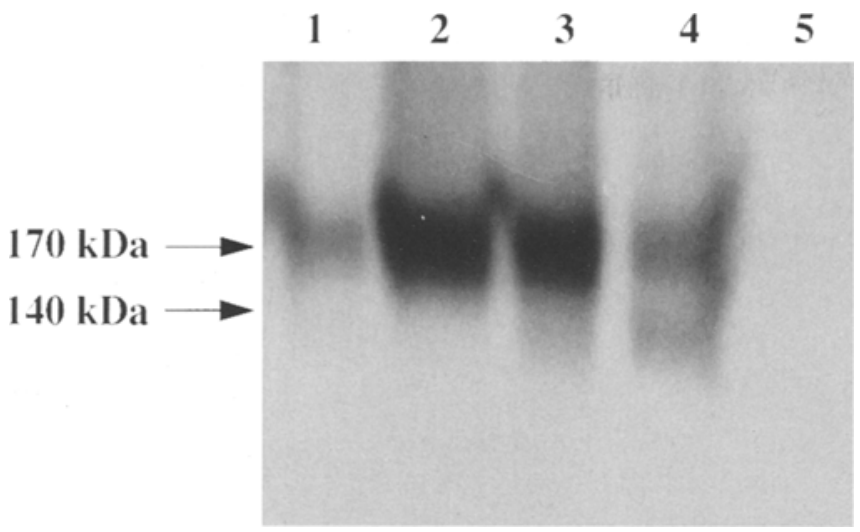

Fig.4. Photoaffinity labelling of sulphonylurea receptors in insulinoma membrane fractions. Membranes $(50 \mu \mathrm{g})$ were incubated with $10 \mathrm{nmol} / 1\left[{ }^{3} \mathrm{H}\right]$ glibenclamide and irradiated at $302 \mathrm{~nm}$ for $15 \mathrm{~min}$ as described in the methods section. Labelled proteins in insulinoma membrane fractions A (track 1 ), B (track 2), C (track 3) and D (track 4) were detected by SDS-PAGE and fluorography. Labelling of fraction D was also carried out in the presence of $1 \mu \mathrm{mol} / 1$ glibenclamide (track 5)

fic activity of receptors on secretory granule membranes. This is consistent with the observation that the levels of sulphonylurea receptors and insulin were correlated in a number of different sources of beta cells which differ markedly in their extent of granulation. The finding that most of these binding sites were intracellular is consistent with previous studies which have shown that the receptors are not sensitive to trypsinolysis of intact cells [28]. These findings support the hypothesis that sulphonylurea receptors might regulate insulin secretion by more than one mechanism and raises the possibility that this could occur through direct interaction of the receptor with granule membrane proteins such as those involved in granule movement or membrane fusion.

Little is known about the structural organization of the sulphonylurea receptor in membranes. Numerous studies employing photoaffinity labelling have shown that the high affinity sulphonylurea binding site is present on a polypeptide chain with an apparent molecular weight of $140 \mathrm{kDa}$ to $150 \mathrm{kDa}[5-7$, 29]. The present photoaffinity labelling approach demonstrated that there are actually two species of sulphonylurea receptor with molecular weights of approximately 140 and $170 \mathrm{kDa}$ in crude membrane preparations of rat islet. CRI-G1 and insulinoma cells. The subcellular distribution of these components in the insulinoma tissue was consistent with that of sulphonylurea binding sites, with a predominant localization to intracellular membranes. A small proportion of the $170 \mathrm{kDa}$ form of the receptor was found in association with subcellular fractions enriched in plasma membrane and the $140 \mathrm{kDa}$ form was present only in the subcellular fraction associated with dense organelles.
The relationship between the two receptors is not clear. It is possible that they are two forms of the same protein which arise from either differential mRNA splicing or post-translational modifications. It is unlikely that the $140 \mathrm{kDa}$ species arises from non-specific proteolysis of the $170 \mathrm{kDa}$ protein because protease inhibitors were present throughout membrane preparation and the relative proportion of the proteins was similar in separate experiments. Electrophysiological studies have shown that application of sulphonylureas to excised plasma membrane patches results in inhibition of $\mathrm{K}_{\mathrm{ATP}}$ channel activity [30]. The presence of the $170 \mathrm{kDa}$ form of the receptor in a subcellular fraction enriched in plasma membranes suggests that it might be the form responsible for regulation of $\mathrm{K}_{\mathrm{ATP}}$ channels. It is less clear why most of the $170 \mathrm{kDa}$ form and all of the $140 \mathrm{kDa}$ receptor are localized to fractions containing a mixture of granules, mitochondria, ER and lysosomes. One possibility is that one or both of the receptors directly mediate exocytotic release of insulin. Another explanation is that these receptors could be associated with granule membrane ion channels which are involved in the regulation of the intragranular environment. Sulphonylurea-sensitive $\mathrm{K}^{+}$identified previously on mitochondrial membranes [31] and zymogen granules [32]. It has been suggested that these channels may play an important role in the fusion of zymogen granule membranes with the plasma membrane. It is possible that sulphonylureas also regulate the fusion of insulin secretory granule membranes with the plasma membrane. The presence of a large intracellular pool of sulphonylurea receptors may also provide a versatile mechanism by which interaction of sulphonylurea receptors with plasma membrane $\mathrm{K}_{\text {ATP }}$ channels could be regulated. For example, stimulation of the cell might result in exocytotic deposition of the granule membrane proteins in the vicinity of $\mathrm{K}_{\mathrm{ATP}}$ channels, and removal of the stimulus might lead to their endocytotic retrieval for intracellular storage. Further studies are warranted to test these possibilities and to determine whether the two forms of the receptor have different activities.

Acknowledgements. This work was supported by grants from the British Diabetic Association, the Medical Research Council of Great Britain and the Wellcome Trust.

\section{References}

1. Ashcroft SJH, Ashcroft FM (1992) The sulphonylurea receptor. Biochim Biophys Acta 1175: 45-59

2. Geisen K, Okomonopoulos HR, Punter J, Weyer R, Summ $\mathrm{H}-\mathrm{D}$ (1985) Inhibition of ${ }^{3} \mathrm{H}$-glibenclamide binding to sulphonylurea receptors by oral antidiabetics. Drug Res 35: $707-712$

3. Gaines KL, Hamilton S, Boyd AE (1988) Characterisation of the sulphonylurea receptor on $\beta$-cell membranes. J Biol Chem 263: 2589-2592 
4. Panten U, Burgfeld J, Goerke F, Rennicke M, Schwanstecher M, Wallasch A, Zunkler BJ, Lenzen S (1989) Control of insulin secretion by sulphonylureas, meglitinide and diazoxide in relation to their binding to the sulphonylurea receptor in pancreatic islets. Biochem Pharmacol 38: 1217-1229

5. Kramer W, Oekonomopulos R, Punter J, Summ HD (1988) Direct photoaffinity labeling of the putative sulphonylurea receptor in rat $\beta$ cell membranes by $\left[{ }^{3} \mathrm{H}\right]$-glibenclamide. FEBS Lett. 229: 335-359

6. Aguilar-Bryan L, Nelson DA, Vu QA, Humphrey MB, Boyd AE (1990) Photoaffinity labeling and partial purification of the $\beta$ cell sulfonylurea receptor using a novel, biologically active glyburide analog. J Biol Chem 265: (14) 8218-8224

7. Nelson DA, Aguilar-Bryan L, Bryan J (1992) Specific photolabeling of $\beta$-cell membrane proteins with an ${ }^{125} \mathrm{I}$-labeled glyburide analogue. J Biol Chem 267: 14928-14933

8. Skeer JM, Dégano P, Coles B, Potier M, Ashcroft FM, Ashcroft SJH (1994) Determination of the molecular mass of the native $\beta$-cell sulfonylurea receptor FEBS Lett 338: 98102

9. Lee K, Ozanne SE, Hales CN, Ashford MLJ (1994) $\mathrm{Mg}^{2+}$ dependent inhibition of $\mathrm{K}_{\mathrm{ATP}}$ by sulphonylureas in CRIG1 insulin-secreting cells. Br J Pharmacol 111: 632-640

10. Khan KN, Hales CN, Ozanne SE, Adogu AA, Ashford MLJ (1993) Dissociation of $\mathrm{K}_{\mathrm{ATP}}$ channel and sulphonylurea receptor in the rat clonal insulin-secreting cell line, CRI-D11. Proc Roy Soc Ser B 253: 225-231

11. Shibier O, Flatt PR, Effendic S, Berggren P-O (1991) Intracellular action of sulphonylureas in the stimulation of insulin release. Diabetologia 34: [Suppl 2] A29 (Abstract)

12. Ammala C, Bokvist K, Eliasson L, Lindstrom $P$, Rorsman $P$ (1993) Tolbutamide stimulates exocytosis by direct interaction with the secretory machinery in $\beta$-cells. Diabetologia 36: [Suppl 1] A60 Abstract

13. Carpentier J-L, Sawano F, Ravazzola M, Malaisse WJ (1986) Internalization of ${ }^{3} \mathrm{H}$-glibenclamide in pancreatic islet cells. Diabetologia 29: 259-261

14. Hutton JC, Penn EJ, Jackson PJ, Hales CN (1981) Isolation and characterisation of calmodulin from an insulin secreting tumour. Biochem J 193: 875-885

15. Hutton JC, Davidson HW, Grimaldi KA, Peshavaria M (1987) Biosynthesis of betagranin in pancreatic beta cells: identification of a chromogranin A-like precursor and its parallel processing with proinsulin Biochem J 244: 449-4.56

16. Carrington CA, Rubery ED, Pearson EC, Hales CN (1986) Five new insulin-producing cell lines with differing secretory properties. J Endocrinology 109: 193-200

17. Guest PC, Rhodes CJ, Hutton JC (1989) Regulation of the biosynthesis of insulin-secretory-granule proteins. Biochem J 257: 431-437

18. Hutton JC, Bailyes EM, Rhodes CJ, Guest PC (1990) Regulation of the biosynthesis and processing of polypeptide hormones. In: JC Hutton, K Siddle (eds) Peptide hormone secretion, pp 309-336

19. Bradford MM (1976) A rapid and sensitive method for the quantitation of microgram quantities of protein using the principle of protein-dye binding. Anal Biochem 72: 248254

20. Hales CN, Randle PJ (1963) Immunoassay of insulin with insulin-antibody precipitate. Biochem J 88: 137-146

21. Cooperstein SJ, Lazarow A (1951) A microspectrophotometric method for the determination of cytochrome oxidase. J Biol Chem 189: 665-670

22. Sottocasa GL, Kuylenstierna B, Ernster L, Bergstrand A (1967) An electron transport system associated with the outer membrane of liver mitochondria. J Cell Biol 32: $415-438$

23. Bowers GN Jr, McComb RB (1975) Measurement of total alkaline phosphatase activity in human serum. Clin Chem 21: 1988-1995

24. Barrett AJ, Heath MF (1977) Lysozomes: a laboratory handbook. In: Dingle JT (ed) North Holland Publishing Co., Amsterdam

25. Laemmli UK (1970) Cleavage of structural proteins during the assembly of the bacteriophage T4 Nature 227: 680-685

26. Nelson DA, Aguilar-Bryan L, Wechsler SW, Bryan J (1993) The high affinity HIT cell sulfonylurea receptor: identification, purification and subunit structure. International Symposium on $\mathrm{K}_{\mathrm{ATP}}$ channels and sulfonylurea receptors, Texas (Abstract)

27. Bryan J, Aguilar-Bryan L, Nelson D (1993) Cloning of a sulfonylurea receptor (ATP-sensitive $\mathrm{K}^{+}$channel?) from rodent $\alpha$ - and $\beta$-cells. International Symposium on $\mathrm{K}_{\mathrm{ATP}}$ channels and sulfonylurea receptors, Texas (Abstract)

28. Lee K, Ozanne SE, Rowe I, Hales CN, Ashford MLJ (1994) The effects of trypsin on ATP-sensitive potassium channel properties and sulfonylurea receptors in the CRIG1 insulin-secreting cell line. Molecular Pharmacol 45: 176-185

29. Bernardi H, Fosset M, Lazdunski M (1988) Characterization, purification and affinity labelling of the brain $\left[{ }^{3} \mathrm{H}\right]$ glibenclamide binding protein, a putative neuronal ATPregulated $\mathrm{K}^{+}$channel. Proc Natl Acad Sci USA 85: 98169820

30. Sturgess NC, Ashford MLJ, Cook DL, Hales CN (1985) The sulphonylurea receptor may be an ATP-sensitive $\mathrm{K}^{+}$ channel. Lancet ii: 474-475

31. Paucek P, Mironova G, Mahdi F, Beavis AD, Woldegiorgis G, Garlid KD (1992) Reconstitution and partial purification of the glibenclamide-sensitive, ATP-dependent $\mathrm{K}^{+}$ channel from rat liver and beef heart mitochondria. J Biol Chem 267: 26062-26069

32. Thévenod F, Chathadi KV, Jiang B, Hopfer U (1992) ATPsensitive $\mathrm{K}^{+}$conductance in pancreatic zymogen granules: block by glyburide and activation by diazoxide. J Mem Biol 129: 253-266 